\title{
PUBLIC TRUST AND FINANCIAL REPORTING GAP: EVIDENCE FROM UNDERLINED ETHICAL ISSUES
}

\author{
OWOLABI SUNDAY .A., OMOTILEWA, OLUWATOYIN .O \\ DEPARTMENT OF ACCOUNTING, BABCOCK UNIVERSITY, NIGERIA \\ owolabi@babcock.edu.ng,olufemiomotilewa@gmail.com
}

\begin{abstract}
Ensuring highest standards of ethics is crucial in preparing financial reports. Shareholders, potential shareholders and other users of the Financial statements rely heavily on the yearly financial statements to make investment decisions. Many studies have been carried out to address the ethics of accounting and Financial reporting but few have considered the effect of lapses in ethical issues on public trust. The study adopted the explorative research design using primary data. The target audience for the study comprised professional accountants and audit firms in Lagos as at May 2020. The results showed that there is a strong positive correlation between public trust and quality of Financial reporting $(r=.959, n=.155, p=.005)$; there is a strong positive association between truthfulness and fairness and quality of Financial reporting $(r=.649, n=155$, $p=.005)$; that the ethical code and the activities of professional accountants have a statistical significant linear relationship ( $r=.897, n=155, p=.005)$, and that there is a strong and positive linear association between quality of reporting and stakeholders level of decision making $(r=.762$, $n=155, p=.000)$. The study concludes that ethical consideration and competence of professional accountant positively and significantly influenced quality of financial reporting which in turn would increase the public trust. The study recommended that Accountants must exhibit truthfulness and fairness in the practice of ethical codes and that financial reporting rules must being strengthened to make financial reporting process transparent and conducive to all stakeholders.
\end{abstract}

Keywords: Public trust, Financial reporting, Ethics, Investment, Stakeholders.

\section{INTRODUCTION}

Financial reports are employed by captains of companies to account for their diligent service to shareholders and other key players. Through the reports, firms present an image of their activities and core values to the society in a fashion that will bolster their reputation, and to render accountability for their activities (Enderlie, 2004). The reports ought to impact the decisionmaking process of a diversity of interest associations which include the shareholders, potential investors, the regulatory bodies, lender and analysists to mention few (Herbert \& Tsegba 2013). Therefore, users may need to ascertain the quality of the reports, in order to ascertain the truthfulness of information for their own decision making, and holding the companies responsible for their decisions. The quality of financial reporting is an indicator of the threshold to which the financial reports of a company, its economic standing, and functions measured across a span of years, are represented creditably (Talabnia (Salehi \& Jabbarzade 2011). 
Trust in the financial reporting system is fundamentally necessary for proper working of the system, and can be perceived a pubic benefit, which should be beneficial to all stakeholders in the system. Trust is built on the veracity and transparency of financial reporting systems. For the financial reporting process to be trusted, the reported numbers must be honest, to reflect the actual states of affairs of the reporting entity, and must be in adequate format. Adequacy of the financial reporting process is important in order to consolidate the trust of the stakeholders and shore up the investment activities in the capital markets. An important input for building trust is that those charged with the responsibilities of preparing financial report must be seen to be trustworthy, competent and having adequate knowledge of their reporting environment. Therefore, the personnel charged with the responsibility of preparing the report must exhibit the moral and legal responsibility to ensure transparency. This can be done by adherence to the reporting rules appropriate criteria for adequate information.

The surge in the cases of corporate crises, leading to scandals and failures of the once perceived high flying companies due to unethical financial reporting practices have raised the questions bordering on the plausibility of financial reports, as it is being discovered that financial reports are falsified in a way that might not present the correct state of affairs of the organization presenting them (Olalere 2010). In this regard, there is now the general belief that financial statements do not reveal the substance of corporate performance, rather, they then are embedded in plethora of formalities making it unworthy and unreliable in taking economic decision.

The various corporate scandals and failures have increased the need to scrutinized the loopholes of the financial reporting process and corporate disclosure requirements due to perceived corporate sharp practices, and attendant negative influence on the perceived credibility of financial reporting, affecting the financial reporting effectiveness (IFAC, 2003). The flexibility allowed by account procedure preparing financial report accords corporate management the opportunities to alter results of financial transactions and their substance through their choice of accounting policy, the application of the guidelines, and outright disregard for ethical conduct to perpetrate fraudulent financial reporting (Milford \& Comskey, 2002).

The general purpose of financial reporting system is to present report of financial transactions and operations about a company in a fair and truthful manner to the interested users of the financial statements. In the opinion of Stice \& Stice (2012) financial statements prepared with element of independence and integrity, which are essential components of ethics reduce errors and offer relevant information for the users of financial reports. This is because users of financial report depend on the accuracy, and truthful presentation of financial statements and auditor's position on whether the statements are showing fair value of the organization (Ronen, 2018). Any deviation resulting from misapplication of GAAP suggest a breach of ethical norms in financial reporting.

Until recently, it was a given that the reports endorsed by publicly acclaimed auditors sufficiently and precisely depicted companies' financial performance (Enderlie 2004). However, the recent wave of corporate scandals which were associated the ethical bankruptcy among the top management of companies including the members of the professional accounting bodies has greatly shaken the users of financial reports confidence. The nosedive of many business firms across the world in the past two decades have presented serious financial consequence to investors, employees and the public, hence there is the credibility problem. Serious doubts and cynicism 
about the current reporting practices have gained ground among the user of financial reports. Therefore, the ethics of financial reporting has been shaking to the foundation level. The ethical lapses among public accountant saddled with financial reporting have called for revision of the accounting professional standards. The sensitive nature of company's financials requires the study of the ethical issues and the roles of the professionals engaged in the process of financial reporting.

Generally, ethics refers to the morals or a code-system that provides the criteria for deciphering between wrong and right (Banerjee \& Ercetin 2004). Ethical dilemmas are recognized to arise in workplace from scenarios where a group or a person must make a choice between two not too pleasant decision options. Accounting ethics has been deemed as herculean to control as accountants and auditors must prioritize the interest of the public, while ensuring that they remained employed by their clients. They must consider how to best employ accounting principles even when confronted with issues that could cause a company to face financial distress or even be liquidated. Ultimately professionals charge with financial roles should note that their relationship to the production of clean and accurate financial statements boosts the reputation of the firm.

Consequent upon these erosion of confidence of the use of financial reports in the financial reporting processes, there must be clear assertion regarding the impact of the organizational codes of ethics and people's personal values of the two most important variable that effect the code of conduct for good governance in corporate world and among the concerned professionals.

In the light of the above, this study seeks to investigate the roles of accounting ethics in improving the credibility of financial reporting process as a means of increasing the trust of the users of financial statement. However, the specific intent of the study includes ascertaining the relationship between financial reporting and public trust; finding out the impact of ethics on the truth and fairness of financial report; ascertaining whether professional code of conduct can influence the conduct of professional accountants; and investigating whether the financial reporting affect the stakeholders' decision-making process.

\section{LITERATURE REVIEW}

\subsection{Empirical Review}

Demonstration of ethical practice by accountants constitutes a major input of services provided for client, this is the bedrock of public accounting practice (Ponemon, 1988). Ethics in accounting indicate a universally accepted code of conduct basically designed to promote good professional practice, integrity in addition to strong commitment to high standards in dealing with clients. (Owolabi, 2002). The principle of good corporate governance requires management of organizations who has agents are in fiduciary relationship with the stakeholders to employ good practices and sound ethical conduct in the management of the organizations for the overall interest of the stakeholders.

The practice of accounting requires good management of personnel for effective and efficient operation. Financial reporting practices is anchored on knowledgeable personnel, with appropriate education, skill and experience backup with professional qualification and adherence to the fundamental ethical principle to be able to perform the wide range of accounting and audit tasks (Stewart \& Subramanian, 2010). There is the general consensus that professional accountants 
should exhibit, confidentiality, integrity, objectivity, professional competence, technical standards and independence as the fundamental ethics and guidelines in all their professional engagements (Agudu, 2006).

Any deviation from the code of ethics by a professional accountant engaged in accounting or audit service will ultimately result in fraudulent financial reporting which will not serve the intended purpose. NACFE (1993); Munford and Chomiskey (2002) define fraudulent financial reporting as the deliberate misstatement or omission of material facts of accounting in order to achieve some set goals. Literature on unethical financial reporting seem to suggest that unethical practices are anchored on pressure from stakeholders, opportunities of weaknesses in system of internal control and rationalization. For instance, Loebbecke, Eining and Willingham (1989) have identified undue pressure of meeting earnings target, need to comply with regulatory requirements, increasing stock prices, the need to bolster financial performance for pending equity or debt financing and concealing a business' declining financial performances as key factors that usually coerce management to resort to unethical financial reporting practices. In the same instance, Lobbecke, Eining and Willingham (1989) posit that low financial expertise of external auditors, will ultimately result to lack of integrity and independence and competence, provide opportunities for management to engage in financial fraud. Payne and Robb (2000) identified management desire to satisfy or exceed security analysts expectation of earnings growth, elimination of negative earnings shocks, and the desire to achieve favorable share price, as major inducements for unethical financial reporting, just as Roychowdhury (2006) identifies the desire to avoid reporting losses as responsible factor.

Aside from the deliberate acts of fraud, Livingston (2002) posits that financial scandal can arise as a result of errors resulting from unethical behaviours and poor judgments from management and business leaders which poor audits has failed to reveal. The collapse of some firms and increased level of fraud over the years resulted to the question of creditability in the accounting profession, as well as the efficiency in corporate governance mechanisms (Zeghal \& Mehdhbi, 2016). There are questions on quality and credibility of financial report. Professional accountants are expected to be reliable due to the status of their professional standards of ethics. Thus, ethics and professionalism are key factors for gaining and retaining the confidence of the clients and the public (Mabil, 2019). Professional accountants are required to uphold certain principles and ethics in financial reporting so as to foster public assurance and confidence for the reliability and credibility of financial statements (Kalshoven, Hartog\&Hoogh, 2011). An understanding and adherence to the ethical practices will enable professional accountants to surmount ethical dilemmas, thereby making informed decisions and correct choices, which may outrightly not benefit the company, but the public who relies on the report from the accountant (Ramanna \& Sletten, 2014). For instance, adherence to the principle of independence frees a professional accountant from management influence when performing accounting services and giving out reports (Belay, 2017).

Independence is critical factor which makes accountants act with integrity, objectivity, equity and free from conflict of interest. Independence in practice means how the accountant should be viewed by the public and others. Accountant need to be independent from those they are supposed to report about for the purpose of performing their duties; and activities without interference, independence with objectivity, improves accuracy and reliability of accountants work and increase the confidence of users' of financial reports (Cohen \& Sayag, 2010). Al-Matari, Al-swide and 
Fadzil (2014) through their study to determine the influence of accountants' independence on financial reporting quality, using qualitative and quantitative measures of effectiveness and efficiency found that financial reporting quality is seen to be the core of corporate accounting, since as a section it keeps track with businesses related with the sector. Independence of accountant was found to significantly and positively influence quality of financial report and affect public trust.

In another study Yosep (2016) examine the effect of accountant's objectivity on financial reports quality in Indian publicly listed money deposit banks. The study revealed that banks which engaged objective auditors rarely attract qualified financial reports. The study concluded that objectivity of accountant positively influenced quality of financial reports. Study conducted by Merjan, Mateja, and Slavka (2017) examined the accountant's ethical perceptions using survey research and probity regression. The study showed that integrity of accountant on the quality of reports has statistical and positive significance. The outcome of the study implies that ethical perceptions represented by the fundamental principle are not the only factors influencing accountants in their work. Paul (2017) examined the effect of ethics in the accounting profession as a means of upholding transparency and provision of accurate financial reporting in the United State of America. The study employed qualitative descriptive research design, using primary data, and chi-square analytical technique. Findings from the study indicate that accountant's roles is dependent on the accounting professional ethics.

Several studies had been conducted to investigate effects of accountant's professional ethics on the quality of financial statement. Their findings indicate that there is a positive significance relationship between adoption of professional ethics and quality of financial reporting (Azona, 2009; Mahde \& Mohsen, 2011; Adogbanna \& Ebimobowei, 2012; Enofe, Edemenya \& Osumbor, 2015; Paul, 2017; Aifuwa, Embele \& Saidu, 2018). Given the position of these studies, it should temporarily be deduced that the application and strict adherence to the ethical principle of professional accountants would improve the accuracy, integrity and truthfulness of financial reporting. This should boost the confidence of uses of the financial reports by any interested user for economic decision.

The ethics of financial reporting has become a serious issue of concern to the participants in the financial sector, due to the financial scandals involving companies regarded as high fliers, when it came to the open that management of companies do engage in certain unethical activities such as non-disclosure of the executives compensations, manipulation of revenues and expenses, fabricated write offs of uncollectible accounts activities involving related party transactions, financial malfeasance among other abnormalities (Vanesco, 1999). The aftermaths from the scandals relating to unethical financial reporting have had wide-spread effect of reduced confidence level and mistrust on the credibility of the corporate reporting process, the impact of the regulatory framework and government controls in strengthening and enforcement of rules within the financial market The combine effects of influence of these is to erode thee efficiencies at the macro level and raised concerned over the efficacy of corporate governance mechanisms and corporate accountability (Deakin \& Konzelmann, 2004; Cohen \& Holder-Webaa, 2006). In many cases the enforcement of existing regulatory framework is done halfheartedly or totally lacking as a result of the self-interest of the active participants involved in the preparation of financial reports, imbibing trust, integrity and reliability into financial reporting system is a 
collective issue of personal and institutional which therefore, require concerted effort to be put in place to harness the organization objective and process, with the structure, policies and culture to influence individuals and system to create a culture of reliable financial reporting system in order to build trust.

In the view of Enderle (2013) this would require a three-level approach that would recognize the indispensable role and collective responsibilities of individuals, organization and the systems. Consequently, the concept of ethics should be modeled on the bases of interpersonal relations and functioning systems, in order to adequately capture the ethical issues facing financial reporting.

\section{Theoretical Framework}

\subsection{Theory of right}

Theory of rights assumes that human beings have an inherent and inalienable freedom which should be regarded (Rand, 1967). It emphasis that any good decision process should not obviate the respect of others people's right and a decision will be wrong if it contravenes the right of another individual.

Basically, rights are discussed under Contractual (legal) rights and natural rights within the natural rights, is the truthfulness which is critical to the functioning of accounting (Zeghal \& Mhedhbi, 2016). All users of financial statements are obligated to the right of accessing accurate and truthful financial information that will facilitate their decision making for alternative allocation of resource strategies. The right demands a moral obligation from professional accountants and a reporting entity to prepare and issue fair and truthful financial reports (Nidermeyer, Dorminey \& Wilson, 2012). On the other hand, the Contractual (legal) are critical for the relationship between an accountant and the client which accords them the right to request for competent and professional financial reporting services. As a consequence, accountants are legally obliged to discharge their duties through to their abilities and within their professional constraints. This thus, required that an accountant possesses the requisite independence, integrity and expertise necessary to perform and deliver quality financial reports to the collective users (Copeland, 2015).

In the light of the above, the theory of right is to provide the basis to explain the usefulness of expertise, independence and integrity on the quality of financial reports.

\subsection{METHODOLOGY}

The study adopted the explorative research design. It was employed in order to obtain the preliminary investigation of the subject matters. It is concerned with discovery of the general nature of the problem at hand and variables that are related to it, this is ideal in a research where there is limited information. The population of this study consisted of professional accountants in one hundred and fifty - seven (157) audit firms in Lagos. A complete enumeration (census) of the population was sampled. A census is a study of every unit, everyone or everything, in a population. Since all the members in the population are the same, this paper adopted homogenous sampling. Homogeneous sampling is a purposive sampling technique that focuses on one particular subgroup in which all the sample members are similar, such as a particular level in an institution of hierarchy. This technique was used because there are only limited numbers of primary data sources who can contribute to the study. It is also good where the research problem requires comparisons between various subgroups (Odugbemi, 2000). For the proper use of this technique all the laws guiding sampling techniques namely, law, statistical regularity and law of inertia of large numbers were adequately guided against (Akin, 2002). 
Questionnaires was used as instrument to collect the required information and distributed to cover all the units of the study population. The questionnaire was designed having gone through empirical and theoretical literature review as it relates to accounting ethics and financial reporting. The measuring instrument had five sections. The first section required basic information about the respondent. The next four sections were dedicated to questions regarding the independent variables (public trust, faithfulness and fairness, code of conduct, stakeholder's decision making). The last section had questions on quality financial reporting. The questionnaire was constructed with only close ended questions. Five-point likert scale questions were used to rate the accounting ethics and quality of financial reports at the commercial banks. The questionnaire was pilot tested before the final drafting. This was done to ensure questionnaire's reliability to obtain the required information. The pilot study involved fifteen independent professional accountants who did not participate in the final study.

Data collected was sorted and analyzed using Statistical Package for Social Sciences (SPSS). Inferential and descriptive data analysis techniques were used in the analysis. As such, the utilization of the descriptive statistics involved percentages and distribution frequencies. These were utilized to facilitate a description of demographic data collected. Inferential statistics to be used included a regression analysis, which helped in deciphering the effects of accounting ethics on the quality of financial reports.

\subsection{Description of Variables}

The Study comprises independent variables Ethical issues proxy by public trust (TF), truth and faithfulness (TF), code of Conduct (CC), and stakeholder decision (SD): dependent variable of Financial reporting (FR).

\subsection{Hypotheses and Model Formulation}

In order to affirm the intent of the study, the following hypotheses were formulated and tested at .05 level of significance.

$\mathrm{Ho}_{1}$ : There is no significant relationship between quality of financial reporting and public trust. $\mathrm{Ho}_{2}$ : There is no significant effects of ethics on the truth and fairness quality of financial reports. $\mathrm{Ho}_{3}$ : Ethical code of conducts has no significant effect on the quality of financial reports.

Ho4: Quality of financial reporting does not have significant effect on stakeholder's decision making.

\section{Model specification}

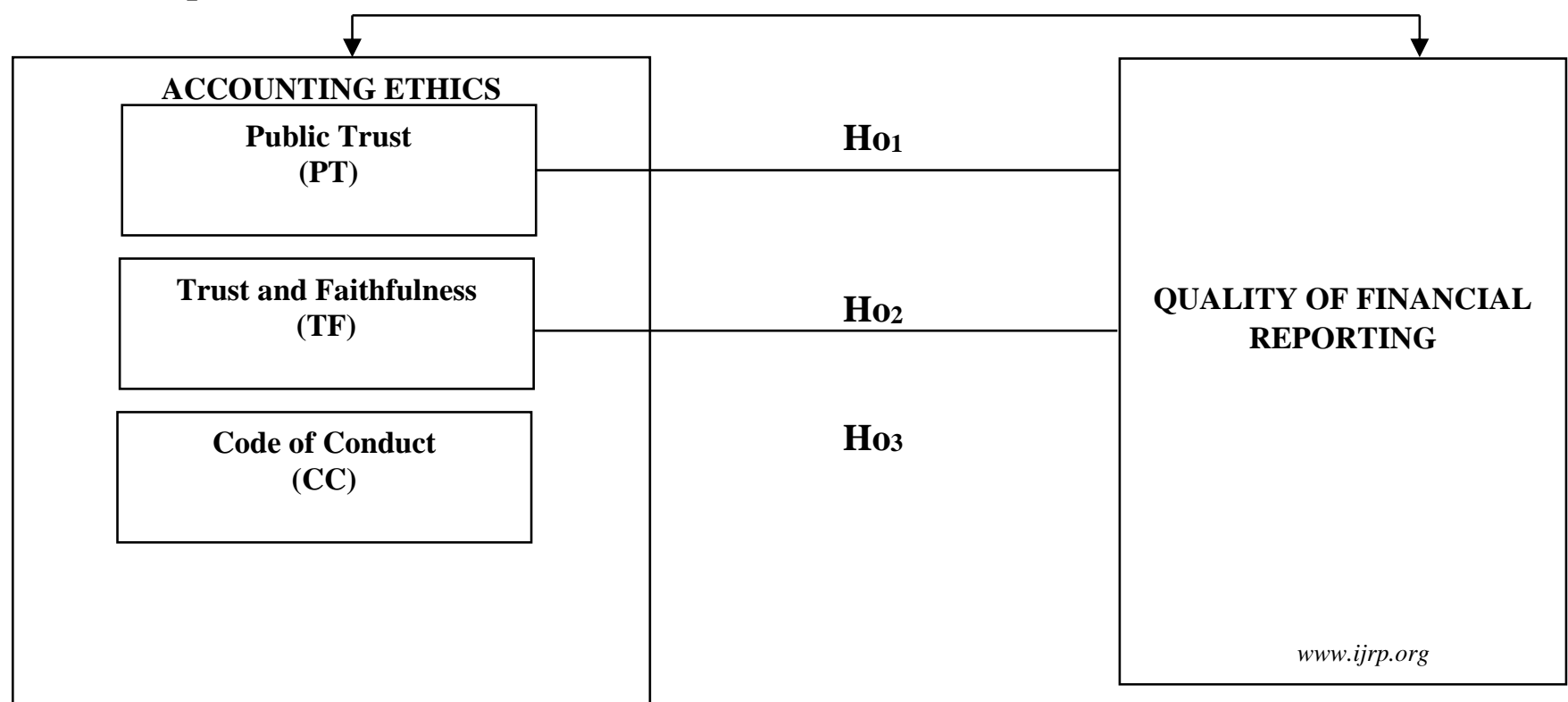


Figure 1.1: Conceptual Model

Source: Researcher's Conceptual Model (2020)

The relationship between the dependent and independent variables used in the study is operationalized and shown in Figure 1.1. The study undertakes the issues of key variables that are likely to influence financial reporting process in Nigeria. All the variables stated below have been structured into the stated hypotheses for testing. They include;

i. Independent variable $(\mathrm{X})$ - Ethical Issues

Proxy by;

$\mathrm{x}_{1}=$ Public Trust $(\mathrm{PT})$

$\mathrm{x}_{2}=$ Truth and Faithfulness $(\mathrm{TF})$

$\mathrm{x}_{3}=$ Code of Conduct $(\mathrm{CC})$

$\mathrm{X}_{4}=$ Stakeholder's Decision (SD)

ii. Dependent variable (Y) - Financial Reporting

For the purpose of this study, a mathematical relationship model was derived as follows from the two variables;

$\mathrm{Y}=\mathrm{f}(\mathrm{X})$ (eq 1$)$

$y=f\left(a_{0}+\beta_{1} x_{1}+e_{1}\right)$

$y=f\left(a_{0}+\beta_{2} x_{2}+e_{2}\right)$

$y=f\left(a_{0}+\beta_{3} x_{3}+e_{3}\right)$

$y=f\left(a_{0}+\beta_{4} x_{4}+e_{4}\right)$

Where:

$\mathrm{f}=$ functional relationship

$\mathrm{e}_{\mathrm{o}}=$ standard error

$\alpha=$ constant factor

$\beta=$ coefficient of Beta

The research study is expected to evaluate the derived models from 1-5 


\subsection{Data Analysis, Interpretation and Discussion.}

\subsection{RESULTS AND DISCUSSION}

Table 1: Respondents General Information

\begin{tabular}{lccc}
\hline Respondent's Sub-sector & Frequency & Percent & Cumulative percent \\
\hline Respondent's Sex & & & 53.5 \\
Male & 83 & 53.5 & 100.0 \\
Female & 72 & 46.5 & \\
Total & $\mathbf{1 5 5}$ & $\mathbf{1 0 0 . 0}$ & \\
& & & 4.5 \\
Respondent's Age & 7 & $4 . .5$ & 43.9 \\
$\mathbf{2 4 - 3 5}$ & 61 & 39.4 & 100.0 \\
\hline 36-47 & 87 & 56.1 & \\
\hline Above 47 years & $\mathbf{1 5 5}$ & $\mathbf{1 0 0 . 0}$ & \\
\hline
\end{tabular}

Source: Fieldwork, 2020

The survey conducted across professional and registered accountant shows that out 157 questionnaires distributed, a total of 155 questionnaires were completely filled and returned, representing $98.7 \%$ response rate. The rate of response was considered extremely high to provide reliable and adequate data for analysis. Table 1 presents that out of 157 sampled respondents, majority $53.5 \%$ were male while $46.5 \%$ represents the female. Fifty-six percent were between the age brackets of 47 years and above, $39.4 \%$ represent the age category of 36-47 years while $4.5 \%$ represent those in the age category of 24-37 years. The result shows that the respondents were well represented. This increases the authenticity of the information supplied.

\section{Public Trust and Quality of Financial Reporting}

Table 2: Correlations

\begin{tabular}{llll} 
& \multicolumn{2}{l}{ Public Trust } & Quality of Financial Reporting \\
\hline Public Trust & \multicolumn{1}{l}{ Pearson Correlation 1} & $.959^{* *}$ \\
\cline { 2 - 3 } & Sig. (2-tailed) & .000 \\
\cline { 2 - 3 } & $\mathrm{N}$ & 155 & 155 \\
\hline \multirow{2}{*}{ Quality of Financial Reporting } & Pearson Correlation $.959^{* *}$ & 1 \\
\cline { 2 - 3 } & Sig. (2-tailed) & .000 & \\
\cline { 2 - 3 } & $\mathrm{N}$ & 155 & 155 \\
\hline
\end{tabular}

Source: Field survey (2020)

**. Correlation is significant at the 0.01 level (2-tailed).

A Pearson product-moment correlation was run to determine the relationship between quality of financial reporting and public trust. Table 2 indicates that there was a strong, positive correlation between the two variables, which was statistically significant $(r=.959, n=155, p=.005)$. Since the p-value is less than our chosen significance level $\alpha=0.05$, the null hypothesis $\left(\mathrm{H}_{\mathrm{o} 1}\right)$ which states that there is no significant relationship between financial reporting and public trust fail to be accepted. 


\section{Truthfulness with Fairness and Quality of Financial Reporting}

Table 4: Correlations

\begin{tabular}{|c|c|c|c|}
\hline & & Truthfulness and Fairness & $\begin{array}{l}\text { Quality of Financial } \\
\text { Reporting }\end{array}$ \\
\hline \multirow[t]{3}{*}{ Truthfulness and Fairness } & Pearson Correlation & 1 & $.649^{* *}$ \\
\hline & Sig. (2-tailed) & & .000 \\
\hline & $\mathrm{N}$ & 155 & 155 \\
\hline \multirow[t]{3}{*}{ Quality of Financial Reporting } & Pearson Correlation & $.649^{* *}$ & 1 \\
\hline & Sig. (2-tailed) & .000 & \\
\hline & $\mathrm{N}$ & 155 & 155 \\
\hline
\end{tabular}

\section{Source: Field survey (2020)}

**. Correlation is significant at the 0.01 level (2-tailed).

The result from Pearson product-moment correlation run to determine the effect of ethics of truthfulness and fairness on the quality of financial reporting as indicates $(r=.649, n=155, p<$ $.005)$ a strong and positive correlation. The more quality of financial reporting, the better the truthfulness and fairness. The null hypothesis $\left(\mathrm{H}_{\mathrm{o} 2}\right)$ which states that there is no significant effects of ethics on the truth and fairness of financial reports failed to be accepted.

\section{Ethical code of conducts and Quality of Financial Reporting}

Table 5: Correlations

\begin{tabular}{|c|c|c|c|}
\hline & & Ethical code of conducts & Quality of Financial Reporting \\
\hline \multirow[t]{3}{*}{$\begin{array}{l}\text { Ethical code of } \\
\text { conducts }\end{array}$} & $\begin{array}{l}\text { Pearson } \\
\text { Correlation }\end{array}$ & 1 & $.897^{* * *}$ \\
\hline & Sig. (2-tailed) & & .000 \\
\hline & $\mathrm{N}$ & 155 & 155 \\
\hline \multirow[t]{3}{*}{$\begin{array}{l}\text { Quality of Financial } \\
\text { Reporting }\end{array}$} & $\begin{array}{l}\text { Pearson } \\
\text { Correlation }\end{array}$ & $.897^{* *}$ & 1 \\
\hline & Sig. (2-tailed) & .000 & \\
\hline & $\mathrm{N}$ & 155 & 155 \\
\hline
\end{tabular}

**. Correlation is significant at the 0.01 level (2-tailed).

The result of Pearson product-moment correlation in Table 5 shows that ethical code of conducts and activities of professional accountant have a statistically significant linear relationship ( $r=$ $.897, n=155, \mathrm{p}<.001)$. The direction of the relationship is positive (i.e. ethical code of conducts and professional accountant quality of financial reporting are positively correlated), meaning that these variables tend to increase together. The magnitude, or strength, of the association is approximately moderate $(.000<|\mathrm{r}|<.5)$. Thus, The null hypothesis $\left(\mathrm{H}_{03}\right)$ which states that ethical code of conducts has no significant effect on the activities of professional accountant fail to be accepted. 


\section{Stakeholder's Decision making Process and Quality of Financial Reporting}

Table 6: Correlations

\begin{tabular}{|c|c|c|c|c|}
\hline & & $\begin{array}{l}\text { Stakeholder's Decision making } \\
\text { Process }\end{array}$ & $\begin{array}{ll}\text { Quality of } \\
\text { Reporting }\end{array}$ & Financial \\
\hline \multirow{3}{*}{$\begin{array}{l}\text { Stakeholder's } \\
\text { Decision making } \\
\text { Process }\end{array}$} & Pearson Correlation & 1 & & $.762^{* *}$ \\
\hline & Sig. (2-tailed) & & & .000 \\
\hline & $\mathrm{N}$ & 155 & & 155 \\
\hline \multirow{3}{*}{$\begin{array}{l}\text { Quality of Financial } \\
\text { Reporting }\end{array}$} & Pearson Correlation & $.762^{* *}$ & & 1 \\
\hline & Sig. (2-tailed) & .000 & & \\
\hline & $\mathrm{N}$ & 155 & & 155 \\
\hline
\end{tabular}

\section{Source: Field survey from SPSS output (2020)}

**. Correlation is significant at the 0.01 level (2-tailed).

The Pearson product-moment correlation test undertaken to determine the relationship between quality of financial reporting and stakeholder's decision making process shows that that there exist a strong and positive linear correlation between the two variables, which was statistically significant $(r=.762, n=155, p<.000)$. The null hypothesis $\left(\mathrm{H}_{01}\right)$ which states that quality of financial reporting does not have significant effect on stakeholder's decision making process was rejected since our $\mathrm{p}$-value lesser than the significance level $\alpha=0.05$. We therefore conclude that quality of financial reporting will positively and significant affect stakeholder's decision making process.

\subsection{Discussion of Findings}

Financial statement quality is a very important element of the infrastructure required to develop a mature financial sector. Therefore, accountants and auditors play a major role in ensuring adequate internal controls in any business organizations and guaranteeing the veracity of the financial information reported in company financial statements. The result of the first hypothesis indicated that quality of financial report was positively and significantly related to public trust. High quality financial reporting is a bedrock of a market-based monitoring of companies, external auditors and other professionals whose work bear upon financial reporting integrity and corporate governance of entities; no matter how remote. This will allow stakeholders' and the public at large to confidently and objectively assess management performance, thus influencing their behavior and decisions.

The results of the simple linear regression analysis showed significant effects of ethics on the truth and fairness quality of financial reports. Professional ethics is important to accountants and those who rely on information provided by accountants because ethical behavior entails taking the moral point of view. This finding is in agreement with that of Ogbonna and Appah (2011) whose study found out that ethical compliance (truth and fairness) by the accountant positively and significantly 
affects the quality financial reports. This is why Brenkert (2004) submits that truthfulness of and trust in the financial reporting system cannot be overemphasized.

The study hypothesis three revealed that ethical code of conducts has significant effect on the quality of financial reports. This result, however, is in consistent with the findings in Flugrath, Bennie and Chen (2007) which indicated that the presence of ethical code of conduct has a positive impact on the quality of the judgment made by professional accountants. The following ethical principles incorporate the characteristics most people associate with ethical behavior; honesty, integrity, promise keeping, loyalty, fairness, caring for others, respect for others, pursuit of excellence and accountability (Enofe, Edemenya and Osunbor, 2015).

This study further found that quality of financial reporting have significant effect on stakeholder's decision making. This result accords substantially with the view expressed in Berrone, suroca, Tribo (2009) that corporate ethical identity was positively related to high levels of stakeholder satisfaction. In turn stakeholder satisfaction had a positive influence on the financial performance of the firm. According to Nwaobia, Kwarbai, Jayeoba and Ajibade (2016) in their research on the effect of financial reporting quality on investment decision using a sample of Nigerian manufacturing firms have stated that higher reporting quality increases investment decision.

\subsection{Conclusion and Recommendations}

\subsection{Conclusion}

This study has focused on the roles of accounting ethics in improving the credibility of financial reporting process as a means of increasing the trust of the users of financial statement. All the objectives of the study are inter-related. The study concludes that ethical considerations and competence of professional accountants positively and significantly influenced quality of financial reports in Lagos, Nigeria. The results of the study has shown that investment decision depends on accounting ethics which rests on credibility of financial reporting. In order to earn public trust, an accountant must exhibit truthfulness and fairness inhibited in the code of conducts and financial reporting should be done in accordance to the Financial Reporting Standards. Hence, the quality matters a lot when it comes to stakeholders' investment decision making. If the quality of the financial reporting is poor, then the financial statements will not be reliable to the investors.

\subsection{Recommendation}

The paper recommended that the regulatory framework of the financial reporting process be strengthened to ensure that the reporting process is transparent, and conducive to ensure strict adherence to ethical principles and corporate governance culture, and whenever necessary timely and appropriate sanction meted out to those found to engage in unethical behavior, in other to ensure strict adherence to the principles of objectivity, independence, fairness and integrity. 


\subsection{Suggestion for further studies}

The paper dealt on the impact of the adherence ethical principles by the accountant to ensure trust and fairness of the financial reporting. it is suggested future studies should extend research to include the readiness of the various stakeholders of a firm to provide the necessary. support to contribute to fair and effective rules of financial reporting.

\section{References}

Aifuwa, H. O., Embele, K., \&Saidu, M. (2018). Ethical Accounting Practices and Financial Reporting quality. EPRA journal of multidisciplinary studies, 15(2); 119-210.

Azona N. M. (2019). Investigating Effects of Accounting Ethics on Quality of Financial Reporting of an Organization: Case of Selected Commercial Banks in South Sudan, 8(1); 7- 15.

Banerjee, S., \& Ercetin, S. S. (2014). Chaos, complexity and leadership 2012. Dordrecht: Springer Science \& Business Media Press.

Brenkert, G.G. (2004). Corporate integrity and accountability. Thousand Oaks

Coetsee, D. (2010). The role of accounting theory in the development of accounting principles. Meditari Accountancy Research, 18(1), 1-16.

Cohen, J. R., \& Holder-Webb, L. L. (2006). Rethinking the influence of agency theory in the accounting academy. Issues in Accounting Education, 21(1), 17-39. http://dx.doi.org/10.2308/iace.2006.21.1.17

Copeland, M. K. (2015). The importance of ethics and ethical leadership in the accounting profession. In Research on professional responsibility and ethics in accounting (pp. 61-98). Bingley: Emerald Group Publishing Limited.

Cressey, D. R. (1953). Other People's Money: A Study in the Social Psychology of Embezzlement. New York, NY, US: Free Press. Retrieved from http://psycnet.apa.org/psycinfo/1954$\underline{06293-000}$

Deakin, S., \& Konzelmann, S. J. (2004). Learning from enron. Corporate Governance, 12(2), 134142.http://dx.doi.org/10.1111/j.1467-8683.2004.00352. 
Enderle, G. (2004). Global competition and corporate responsibilities of small and medium-sized enterprises. Business Ethics-A European Review, 13,51-63. http://dx.doi.org/10.1111/j.1467-8608.2004.00349.

Enofe, A.O., Edemenya, C.C. \& Osunbor, E.O. (2015). The Effect of Accounting Ethics on the Quality of Financial Reports of Nigeria Firms. Research Journal of Finance and Accounting, 6(12), 123-130.

Jetuah, D. (2007). Cadbury auditor steps down 'by mutual agreement'. Retrieved from http://www.accountancyage.com/aa/news/1777200/cadbury-auditor-steps-mutual-agreement

Marjan O., Mateja J., Anton J., \&Slavka K. (2017). Accountants' Ethical Perceptions from Several Perspectives: Evidence from Slovenia. Economic Research-EkonomskaIstraživanja, 30(1); 1785-1803,

Masoud, B., \&Mahbube, A. (2013). Impact of Professional Ethics on Financial Reporting Quality. American-Eurasian Network for Scientific Information, 7(10), 2862-2866.

Mihret, D. G. \& Woldeyohanes, G. Z. (2011). The role of the internal audit function in the disclosure of material weaknesses. The Accounting Review, 86(1), 287-323.

Neidermeyer, P. E., Dorminey, J., \& Wilson, A. J. (2012). Cultural factors, economic affiliations and the adoption of international financial reporting standards. The Journal of Applied Business Research, 28(5), 815 - 824.

Nwaobia, A.N., Kwarbai, J.D. Jayeoba, O.O. \& Ajibade, A.T. (2016). Financial Reporting Quality on Investors' Decisions. International Journal of Economics and Financial Research, 2(7), 140-147.

Ogbonna, G. N., and Ebimobowei, A. (2011). Effect of Ethical Accounting Standards on the Quality of Financial Reports of Banks in Nigeria. Current Research Journal of Social Sciences.

Ogbonna, G.N., \& Appah, E. (2011). Ethical compliance by the accountant on the quality of financial reporting and performance of quoted companies in Nigeria. Asian Journal of Business Management, 3(3), 152-160.

Olalere, T. (2010).Methodology in accounting research: A critique of taxonomy. Retrieved from http://ssrn.com/abstract=1921192

Onu, E. (2007). Akintola williams deloitte: Battling confidence crisis. BusinessWeek, March 4. 
Owolabi, A. A. (2002), "Professional commitment and rule observance among Nigerian

Paul. J ( 2017). Ethics in Accounting Profession and Financial Reporting Quality. New York, Journal of Finance and Accountancy. 5(2); 65- 87.

Rezaee, Z. (2009). Financial statement fraud: Prevention and detection (2nd ed.). New York: John Wiley \& Sons, Inc. Retrieved from http://eu.wiley.com/WileyCDA/WileyTitle/productCd0470455705.html.

Roychowdhury, S. (2006). Earnings management through real activities manipulation. Journal of Accounting and Economics, 42, 335-370. http://dx.doi.org/10.1016/j.jacceco.2006.01.002

Smith, G., (2015). Communication skills are critical for internal auditors. Managerial Auditing Journal, 20(5), 513-519.

Soltani, B. (2009). A closer look at financial reporting: Understanding the fraud risks associated with corporate reporting is vital to maintaining organizational well-being. Retrieved from http://www.thefreelibrary.com

Stice, E. K., \& Stice, J. D. (2012). Intermediate accounting. Mason, OH: South-Western/Cengage Learning Press.

Waweru, N. M., Ntui, P. P., \& Mangena, M. (2011). Determinants of different accounting methods choice in Tanzania: A positive accounting theory approach. Journal of Accounting in Emerging Economies, 1(2), 144-159.

Yosep, M. (2016). Effect Competencies, Integrity, Objectivity of the Function of Internal Audit (Implications for Quality Financial Reporting). European Journal of Accounting, Auditing and Finance Research, 4 (5), 57-72.

Zeghal, D. \&Mhedhbi, K. (2016). An analysis of the factors affecting the adoption of international accounting standards by developing countries. The International Journal of Accounting, 41(4), 373-386. 